Perspective

\title{
Fire from the Sky in the Anthropocene
}

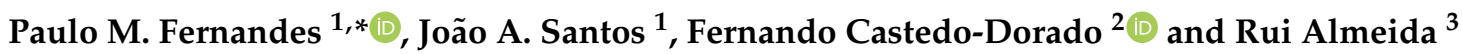 \\ 1 Centro de Investigação e Tecnologias Agroambientais e Biológicas, Universidade de Trás-os-Montes e Alto \\ Douro, Quinta de Prados, 5000-801 Vila Real, Portugal; jsantos@utad.pt \\ 2 Departamento de Ingeniería y Ciencias Agrarias, Universidad de León, Escuela de Ingeniería Agraria y \\ Forestal, Avda. de Astorga s/n, 24401 Ponferrada, Spain; fcasd@unileon.es \\ 3 Instituto da Conservação da Natureza e das Florestas, Avenida da República, 16, 1050-191 Lisbon, Portugal; \\ rui.almeida@icnf.pt \\ * Correspondence: pfern@utad.pt
}

check for

updates

Citation: Fernandes, P.M.; Santos,

J.A.; Castedo-Dorado, F.; Almeida, R.

Fire from the Sky in the

Anthropocene. Fire 2021, 4, 13.

https://doi.org/10.3390/fire4010013

Received: 17 February 2021

Accepted: 11 March 2021

Published: 12 March 2021

Publisher's Note: MDPI stays neutral with regard to jurisdictional claims in published maps and institutional affiliations.

\begin{abstract}
Lightning-caused fires (LCFs) and fire environments influenced by thunderstorms are increasingly implicated in extreme wildfire events around the world, with devastating consequences to society and the environment. However, the disaster potential inherent to LCFs is often neglected, especially where the fire regime is determined mostly by anthropogenic ignitions. Such disconnect between perceived risk and actual risk is illustrated with the Iberian Peninsula, where thunderstormdriven wildfires are comparatively rare but have resulted in large-scale burning and considerable loss of human life. Even low LCF regions should embrace fire management strategies able to cope with LCFs.
\end{abstract}

Keywords: lightning-caused fires; extreme wildfire events; pyroconvection; fire regime; fire management; climate change; Portugal; Spain

\section{Introduction}

Lightning is the prevailing ignition source in many remote or scarcely populated parts of the world, and those fires tend to be larger and more intense than human-caused fires [1]. "Dry" lightning storms can ignite many fires over short periods of time and relatively vast areas and in locations less predictable and accessible than those of human-caused fires. Additionally, and regardless of the ignition cause, thunderstorm wind flows can drastically change the behaviour of on-going fires, amplifying fire-atmosphere interactions and leading to erratic and destructive firestorms. Such was the case of the Pedrogão Grande wildfire in Portugal, where 66 people died on 17 June 2017 [2]. Fires themselves can generate lightning when pyrocumulonimbus form, as in the Black Saturday fires of February 2009 in Australia, where 173 people perished [3]. In 2019-2020, the unprecedented Black Summer mega-fires were mostly lightning-caused fires (LCFs) and burned one-fifth of the Australian temperate broadleaf forest and caused huge social disruption [4]; lightning started most fires in a region where "dry" thunderstorms are now more frequent than in the recent past [5]. Once rare in Tasmania, LCFs are now threatening World Heritage forests non-adapted to fire [6]. In California, the unusual 2020 lightning siege has burned ca. 1 million hectares, destroying at least 4390 structures and killing 22 people after 14,000 lightning strikes [7].

In human-dominated landscapes, such as in southern Europe, LCFs comprise a small fraction of the total number of fires, and so are commonly perceived as irrelevant. Such neglect and focus on human agency can happen even when fire statistics indicate a significant role of LCFs in the fire regime, e.g., in temperate Australia [8]. Consequently, by downplaying or ignoring LCFs, fire management planning will hardly be prepared to handle the particular difficulties posed by an LCF crisis. Here, we characterize the relevance of LCFs in a generically low LCF region, the Iberian Peninsula, and will then address current and future challenges posed by LCFs in relation to climate change. 


\section{Lightning-Caused Fires in the Iberian Peninsula}

Our assessment of the distinctive characteristics and relevance of LCFs in the Iberian Peninsula is based on a literature review for Spain, and on the analysis of official fire records for Portugal [9], a country for which there is no published research on the subject. The distribution of mean elevation, slope, and road density within the $1 \mathrm{~km}^{2}$ enclosing the coordinates of each fire ignition, plus the indices of the Canadian Forest Fire Weather Index (FWI) System, were computed for human-caused fires and LCFs in Portugal $(\geq 0.01$ ha, 2001-2020).

LCFs accounted for an average of $4.1 \%$ of all wildfires ( $\geq 0.01 \mathrm{ha}$ ) and $5 \%$ of the total surface burned in Spain throughout 1968-2015. These are modest figures, notwithstanding high spatial variability, with LCFs accounting for more than half of the total number of wildfires in some regions [10]. Most LCFs in Spain burn less than 1 ha [11,12] because of early extinction, either by thunderstorm precipitation or fire-fighting action. Conversely, lightning caused some of the largest fires recorded in Spain. In the 1968-2015 period, three LCFs exceeded 25,000 ha in size: the Ayora wildfire, in the border between the Cuenca and Castellón provinces in 1978; and the 1994 Villarluengo and Millares wildfires in the Valencia province $[13,14]$. These three wildfires are among the largest historically reported in Spain. The maximum annual area burned by LCFs was reached in 1994 (more than 112,000 ha), with almost 75,000 ha burned by three large wildfires initiated during a sequence of "dry" thunderstorm days from the 2nd to the 5th of July in the Comunitat Valenciana region. A similar event occurred in the Teruel province on 22 July 2009, when three LCFs nearly burned 10,000 ha. In the 2001-2010 period, LCFs accounted for approximately $25 \%$ of the wildfires larger than 3000 ha [15].

People-caused fires and LCFs in Spain differ in seasonal distribution, geographic location, physiography and vegetation composition at the ignition site, and the degree of fuel dryness at the time of ignition. Most LCFs in Spain occur during summer (June to September) $[12,16,17]$, when atmospheric instability and mid-level moisture foster the development of convection processes and lightning activity $[18,19]$ and litter and duff moisture contents are diminished by drought [20]. Nevertheless, a common nationwide pattern is absent for some of those features, and the variables may operate differently depending on the scale of analysis [20,21].

Although widely dispersed throughout Spain, LCFs are more clustered in certain regions, mainly in the eastern part of the country, in the mountain ranges bordering the Mediterranean, and along the mountain ranges towards the interior (the Iberian System, Pyrenees, and some parts of the Central System). These geographic patterns roughly agree with the pattern of the number of days with summer storm activity [16]. LCFs tend to occur at higher elevations than anthropogenic fires where both types of ignition origins are common [16], which can be attributed to increased lightning density with elevation due to the orographic effect on convective development [18]. Nevertheless, elevation can regionally decrease LCF likelihood $[17,21,22]$, probably because of higher precipitation and lower temperatures at higher elevations. The influence of aspect on LCF probability seems to depend on the scale of analysis. North-facing aspects are expectedly less likely to ignite from lightning and support fire spread due to comparatively lower insolation and wetter fuels, e.g., [11]. The influence of aspect can, however, be masked by other biophysical influences [21]. LCF probability is usually higher in steeper terrain [17], although the association is non-linear and, again, may depend on the scale of analysis.

LCFs tend to initiate in and affect more forest than human-induced fires [16], as lightning often strikes trees. More specifically, LCFs are more likely to initiate in conifer and mixed forests than in broadleaf forests $[11,17,21]$. Ignition by lightning is strongly dependent on fuel moisture content, which needs to be low enough for the energy of the lightning strike to produce combustion. As such, LCF likelihood increases when the Duff Moisture Code (DMC) of the Canadian FWI System increases [20,21].

LCFs in Portugal comprise $1.1 \%$ of the total number of fires, thus they are proportionally less than in Spain, but account for a larger fraction (7.5\%) of the total burned area. 
Comparing the two countries in this respect is debatable because the figures are for different time periods; ignition density is substantially higher in Portugal, and the fraction of fires with a known cause differs greatly between the two countries-88\% in Spain (2006-2015) but only $44 \%$ in Portugal. The year most marked by lightning-fire activity was 2003, with 68,315 ha burned by LCFs, mostly between 31 July and 15 August. This period corresponds to an uninterrupted daily sequence of LCFs that account for $24.1 \%$ of the number of fires and $44.3 \%$ of the total burned area during the period, considering only the subset of fires with an attributed cause. Actually, the area burned by LCFs during the period may be substantially higher, as the causes of 5429 fires that burned 173,085 ha remain unknown and records do not include rekindles from LCFs. Regardless of the ignition source, 18 fires grew beyond 3000 ha under the "dry" thunderstorm environment prevailing in central-eastern Portugal during early August 2003, including the country's fastest-spreading fires during 2003-2016 [23]. A similar fire environment determined the extreme fire behaviour and deadly consequences of the June 2017 fires [2].

LCFs in Portugal are predominantly (66.8\%) smaller than 1 ha, but comprise $15.6 \%$ of the fires $>3000$ ha, and the largest LCFs tend to be larger than the largest human-caused fires, e.g., the 97.5th percentiles are, respectively, 470.2 ha and 68.5 ha. Similarly to Spain, LCFs burn proportionally more forest (65.3\% of their total area) than anthropogenic fires $(44.6 \%)$, and LCF events occur essentially $(93.1 \%)$ in June-September. LCFs are further distinguished from human-caused fires by the propensities to start in higher elevation and remote territory, delaying detection and suppression action, and to ignite drier fuels under windier conditions, hence developing higher fire intensity and growing potentially larger (Figure 1).
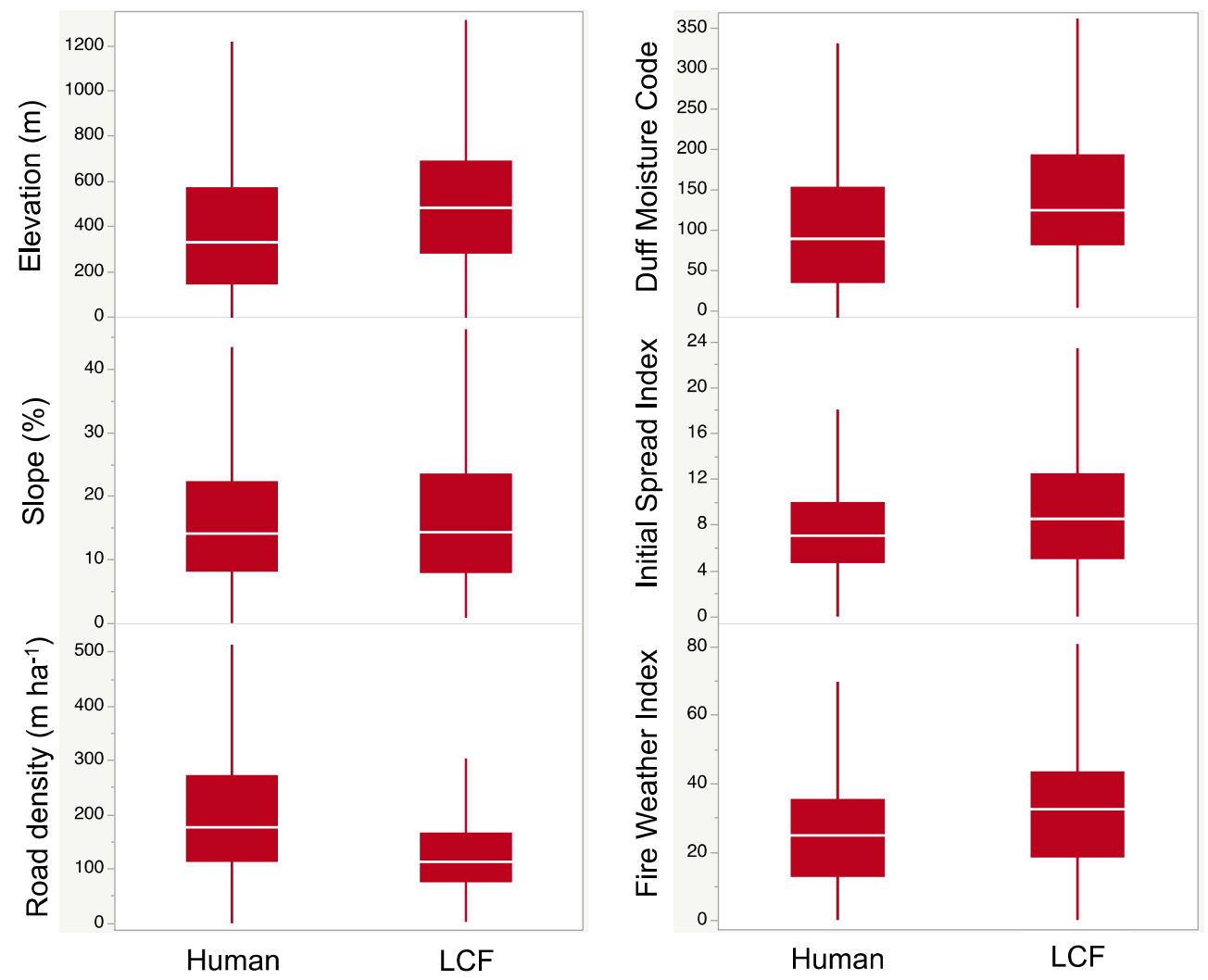

Figure 1. Box plots of variables relevant to wildfire behaviour and suppression, individualized by human and lightning-caused (LCF) fires and for Portugal (2001-2020). The Duff Moisture Code, Initial Spread Index, and Fire Weather Index are components of the Canadian Forest Fire Weather Index (FWI) System and, respectively, indicate forest floor dryness, the combined effect of wind speed and fine dead fuel moisture content on fire-spread rate, and potential fireline intensity. 
The normalization of the number of LCFs per unit area reveals higher incidence in Spain than in Portugal (Figure 2). This would be expected given the higher degree of climate continentality in the former and is consistent with decreasing seasonal alignment between lightning and fuel moisture from eastern to western Iberia [24]. Regression analysis indicates a 3-fold increase in the number of LCFs in Portugal during 2001-2020. A trend is not apparent for Spain, which might be hindered by regional variability over a much larger landmass.

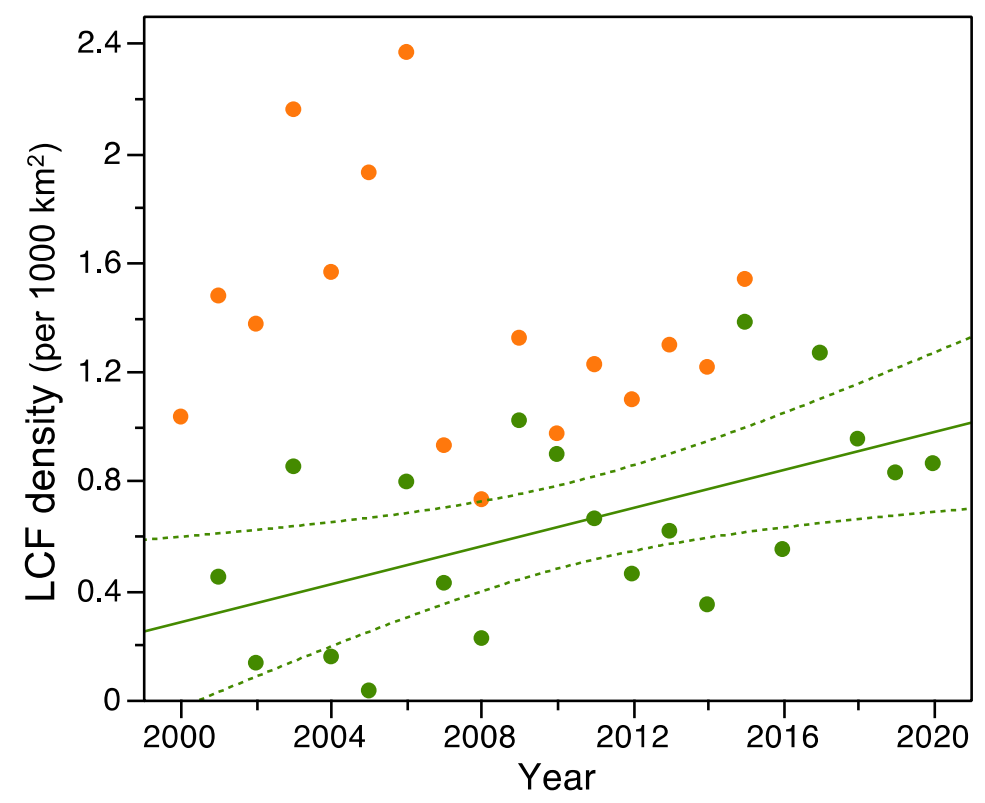

Figure 2. Density of lightning-caused fires (LCFs) in Spain (2000-2015, orange dots) and Portugal (2001-2020, green dots). The linear regression (showing the $95 \%$ confidence interval) is fit to the Portuguese data $\left(p=0.012, r^{2}=0.302\right)$.

\section{Conclusions: Current and Future Global Challenges}

Contemporary increases in LCFs reported in the literature (and the trend in Figure 2) can result from higher lightning ignition efficiency due to increased fuel load or decreased fuel moisture [25,26], rather than increased lightning. Nonetheless, climate warming is expected to intensify lightning activity in many regions worldwide as a result of the strengthening of atmospheric potential energy available for convection, vertical wind shear, and convective instability [27]. These are indeed key dynamical factors for developing deep convective structures, such as supercells, which commonly trigger severe thunderstorms and intense lightning activity. In the United States, recent past trends in lightning activity are spatially diverse and comprise significant uncertainties [28], but lightning is, in general, projected to increase under future warmer climates [29-31].

As recently seen in Portugal, Australia, and the United States, the concurrence of "dry" lightning with flammable vegetation, preconditioned by drought, leads to conflagrations that easily overwhelm fire-fighting efforts and severely impact human life, property, and ecosystem services. The climate change attribution of lightning events causing large-scale burning remains elusive [32] and scientifically underdeveloped [33], but the inherent threat to society is serious enough to uphold adequate mitigation and adaptation in the quest to live with fire in the Anthropocene.

Anticipation is key in responding to potential LCF events, namely through improved fire danger rating systems integrating atmospheric instability indicators and by increasing fire-suppression readiness to deal with simultaneous fires in less accessible locations. While LCFs are unavoidable, their outcomes in terms of wildfire spread, energy release, and impacts can be substantially moderated. Expanding strategically placed fuel-reduction 
treatments and increasing the resistance of structures to ignition and the awareness of people living at the wildland-urban interface would achieve such an endeavour.

Author Contributions: Conceptualization, P.M.F.; investigation, P.M.F., J.A.S., F.C.-D., R.A.; data curation, P.M.F., R.A.; writing-original draft preparation, P.M.F., J.A.S., F.C.-D.; writing-review and editing, P.M.F., J.A.S., F.C.-D., R.A. All authors have read and agreed to the published version of the manuscript.

Funding: This work is supported by National Funds by FCT-Portuguese Foundation for Science and Technology, under the project UIDB/04033/2020.

Institutional Review Board Statement: Not applicable.

Informed Consent Statement: Not applicable.

Data Availability Statement: The data presented in this study are partially available at http:// www2.icnf.pt/portal/florestas/dfci/inc/estat-sgif\#list (accessed on 16 February 2021). Restrictions apply to the availability of the complete data set, obtained from Instituto da Conservação da Natureza e das Florestas ICNF and available from the authors upon ICNF permission.

Conflicts of Interest: The authors declare no conflict of interest. The funders had no role in the writing of the manuscript.

\section{References}

1. Cattau, M.E.; Wessman, C.; Mahood, A.; Balch, J.K. Anthropogenic and lightning-started fires are becoming larger and more frequent over a longer season length in the U.S.A. Glob. Ecol. Biogeogr. 2020, 29, 668-681. [CrossRef]

2. Guerreiro, J.; Fonseca, C.; Salgueiro, A.; Fernandes, P.; Lopez, E.; de Neufville, R.; Mateus, F.; Castellnou, M.; Silva, J.S.; Moura, J.; et al. Análise e Apuramento dos Factos Relativos aos Incêndios que Ocorreram em Pedrógão Grande, Castanheira de Pêra, Ansião, Alvaiázere, Figueiró dos Vinhos, Arganil, Góis, Penela, Pampilhosa da Serra, Oleiros e Sertã entre 17 e 24 de Junho de 2017; Assembleia da Républica: Lisboa, Portugal, 2017.

3. Dowdy, A.J.; Fromm, M.D.; McCarthy, N. Pyrocumulonimbus lightning and fire ignition on Black Saturday in southeast Australia. J. Geophys. Res. Atmos. 2017, 122, 7342-7354. [CrossRef]

4. Boer, M.; Dios, V.R.; Bradstock, R. Unprecedented burn area of Australian mega forest fires. Nat. Clim. Chang. 2020, 10, 171-172. [CrossRef]

5. Dowdy, A. Climatology of thunderstorms, convective rainfall and dry lightning environments in Australia. Clim. Dyn. 2020, 54, 3041-3052. [CrossRef]

6. Kirkpatrick, J.B.; Styger, J.K.; Marsden-Smedley, J.B. Impact of changes in lightning fire incidence on the values of the Tasmanian wilderness world heritage area. Pap. Proc. R. Soc. Tasman. 2020, 152, 27-32. [CrossRef]

7. CAL FIRE California Daily Update. Available online: https://www.fire.ca.gov/daily-wildfire-report/ (accessed on 15 September 2020).

8. Egloff, B. Lightning strikes: Rethinking the nexus between Australian Indigenous land management and natural forces. Aust. For. 2020, 80, 275-285. [CrossRef]

9. ICNF, Estatísticas de Incêndios Florestais. Available online: http://www2.icnf.pt/portal/florestas/dfci/inc/estat-sgif\#list (accessed on 14 December 2020).

10. Martínez, J.; Martínez -Vega, J.; Martín, M.P. El factor humano en los incendios forestales: Análisis de factores socioeconómicos relacionados con la incidencia de incendios forestales en España. In Nuevas Tecnologías para la Estimación del Riesgo de Incendios Forestales; Chuvieco, E., Martín, P., Eds.; CSIC: Madrid, Spain, 2004; pp. 101-142.

11. Rodríguez-Pérez, J.R.; Ordóñez, C.; Roca-Pardiñas, J.; Vecín-Arias, D.; Castedo-Dorado, F. Evaluating lightning-caused fire occurrence using spatial generalized additive models: A case study in central Spain. Risk Anal. 2020, 40, 1418-1437. [CrossRef]

12. Pineda, N.; Rigo, T. The rainfall factor in lightning-ignited wildfires in Catalonia. Agric. For. Meteorol. 2017, 239, 249-263. [CrossRef]

13. ICONA, Los incendios forestales en España durante 1979. Available online: https:/ /www.mapa.gob.es/es/desarrollo-rural/ estadisticas/incendios_forestales_espania_1979_tcm30-132553.pdf (accessed on 10 December 2020).

14. MAPA, Los Incendios Forestales en España Durante 1994. Available online: https://www.mapa.gob.es/es/desarrollo-rural/ estadisticas/incendios_forestales_espania_1994_tcm30-132542.pdf (accessed on 11 December 2020).

15. MAGRAMA. Los Incendios Forestales en España. Decenio 2000-2010; Ministerio de Agricultura, Alimentación y Medio Ambiente: Madrid, Spain, 2012.

16. Vázquez, A.; Moreno, J.M. Patterns of lightning- and people-caused fires in Peninsular Spain. Int. J. Wildland Fire 1998, 8, 103-115. [CrossRef]

17. Vecín-Arias, D.; Castedo-Dorado, F.; Ordóñez, C.; Rodríguez-Pérez, J.R. Biophysical and lightning characteristics drive lightninginduced fire occurrence in the central plateau of the Iberian Peninsula. Agric. For. Meteorol. 2016, 225, 36-47. [CrossRef] 
18. Rivas-Soriano, L.; de Pablo, F.; Tomas, C. Ten-year study of cloud-to-ground lightning activity in the Iberian Peninsula. J. Atmos. Sol. Terr. Phys. 2005, 67, 1632-1639. [CrossRef]

19. Santos, J.A.; Reis, M.A.; Pablo, F.D.; Rivas-Soriano, L.; Leite, S.M. Forcing factors of cloud-to-ground lightning over Iberia: Regional-scale assessments. Nat. Hazards Earth Syst. Sci. 2013, 13, 17451758. [CrossRef]

20. Pacheco, C.E.; Aguado, I.; Nieto, H. Análisis de ocurrencia de incendios forestales causados por rayo en la España peninsular. Geofocus 2009, 9, 232-249.

21. Nieto, H.; Aguado, I.; García, M.; Chuvieco, E. Lightning-caused fires in Central Spain: Development of a probability model of occurrence for two Spanish regions. Agric. For. Meteorol. 2012, 162-163, 35-43. [CrossRef]

22. Nieto, H.; Aguado, I.; Chuvieco, E. Estimation of lightning-caused fires occurrence probability in central Spain. In Proceedings of the 5th International Conference on Forest Fire Research, Figueira da Foz, Portugal, 27-30 November 2006.

23. Andela, N.; Morton, D.C.; Giglio, L.; Paugam, R.; Chen, Y.; Hantson, S.; van der Werf, G.; Randerson, J.T. The Global Fire Atlas of individual fire size, duration, speed and direction. Earth Syst. Sci. Data 2019, 11, 529-552. [CrossRef]

24. Coughlan, M.R.; Magi, B.I.; Derr, K.M. A global analysis of hunter-gatherers, broadcast fire use, and lightning-fire-prone landscapes. Fire 2018, 1, 41. [CrossRef]

25. Bates, B.C.; McCaw, L.; Dowdy, A.J. Exploratory analysis of lightning-ignited wildfires in the Warren Region, Western Australia. J. Environ. Manag. 2018, 225, 336-345. [CrossRef]

26. Styger, J.; Marsden-Smedley, J.; Kirkpatrick, J. Changes in lightning fire incidence in the Tasmanian Wilderness World Heritage Area, 1980-2016. Fire 2018, 1, 38. [CrossRef]

27. Chen, J.; Dai, A.; Zhang, Y.; Rasmussen, K.L. Changes in convective available potential energy and convective inhibition under global warming. J. Clim. 2020, 33, 2025-2050. [CrossRef]

28. Qie, K.; Tian, W.; Wang, W.; Wu, X.; Yuan, T.; Tian, H.; Luo, J.; Zhang, R.; Wang, T. Regional trends of lightning activity in the tropics and subtropics. Atmos. Res. 2020, 242, 104960. [CrossRef]

29. Romps, D.M.; Seeley, J.T.; Vollaro, D.; Molinari, J. Projected increase in lightning strikes in the United States due to global warming. Science 2014, 346, 851-854. [CrossRef]

30. Fill, J.M.; Davis, C.N.; Crandall, R.M. Climate change lengthens southeastern USA lightning-ignited fire seasons. Glob. Chang. Biol. 2019, 25, 3562-3569. [CrossRef] [PubMed]

31. Tippett, M.K.; Allen, J.T.; Gensini, V.A.; Brooks, H.E. Climate and hazardous convective weather. Curr. Clim. Chang. Rep. 2015, 1, 60-73. [CrossRef]

32. Partain, J.; Alden, S.; Bhatt, U.; Bieniek, P.; Brettschneider, B.; Lader, R.; Olsson, P.; Rupp, T.; Strader, H.; Thoman, R.; et al. An assessment of the role of anthropogenic climate change in the Alaska fire season of 2015. Bull. Am. Meteorol. Soc. 2016, 97, S14-S18. [CrossRef]

33. Macias Fauria, M.; Michaletz, S.; Johnson, E. Predicting climate change effects on wildfires requires linking processes across scales. WIREs Clim. Chang. 2011, 2, 99-112. [CrossRef] 